\title{
Opportunities for detection and use of QTL influencing seasonal reproduction in sheep: a review
}

\author{
David R. NOTTER ${ }^{a *}$, Noelle E. COCKETT ${ }^{\mathrm{b}}$ \\ ${ }^{a}$ Department of Animal and Poultry Sciences, Virginia Polytechnic Institute and State \\ University, Blacksburg, Virginia, USA \\ ${ }^{\mathrm{b}}$ Department of Animal, Dairy and Veterinary Sciences, Utah State University, \\ Logan, Utah, USA
}

(Accepted: 16 August 2004)

\begin{abstract}
Genetic improvement in traits associated with seasonal breeding in sheep is challenging because these traits have low heritabilities, are generally not expressed until late in life, are commonly recorded only in females, and are expressed only in some lambing seasons and management systems. Detection of quantitative trait loci and their use in markerassisted selection could therefore substantially enhance selection responses. A population of sheep with an extended breeding season was developed through selection for fertility in spring matings and provides opportunities for further study of candidate genes influencing seasonal breeding. In particular, the melatonin receptor $1 a$ gene is polymorphic in many sheep breeds and appears to influence a number of seasonal reproductive responses. In addition, a variety of clock genes have been identified in laboratory mammals and shown to influence biological rhythms. Mutations in these clock genes have been identified and shown to influence circadian periodicities and reproductive patterns in golden hamster and mouse. In sheep, expression of clock genes in the suprachaismatic nucleus and pars tuberalis (PT) suggests that "calendar" cells in the ovine PT play a role in maintaining circannual rhythms. Thus the various clock genes represent potentially important candidate genes that may be involved in control of seasonal breeding.
\end{abstract}

sheep / seasonal breeding / selection / melatonin receptor la / clock genes

\section{INTRODUCTION}

Seasonal variation in fertility is an important factor limiting efficiency of sheep production. Suboptimal fertility in spring and early summer imposes both a direct biological cost for maintenance of nonpregnant ewes and an opportunity cost associated with inadequate supplies of freshly harvested meat

\footnotetext{
*Corresponding author: drnotter@vt.edu
} 
to fulfill consumer demands throughout the year. Differences among sheep breeds in timing and duration of the seasonal anestrus are well known, with reviews by Hafez [11], Hunter [12], and Notter [27]. Systems for accelerated lambing began to appear in the literature in the 1960's (e.g., $[33,44])$, and indicate that systems involving an 8-mo production cycle (i.e., three lambings in 2 years) are feasible and consistent with the physiology of the ewe. In contrast, more intensive programs involving twice-yearly lambing with a production cycle of $183 \mathrm{~d}$ require very rapid rebreeding and appear not to be practical [48].

The STAR accelerated system [16] uses a 7.2-mo (219 d) production cycle with a 30-d breeding season and $73 \mathrm{~d}$ from the start of lambing until rebreeding. This is likely the most intensive program that is potentially feasible on a whole-flock basis. Rules proposed for scaling biological intervals to the mature size of the species [41] suggest that an interval between lambings of 7.1 mo for $70 \mathrm{~kg}$ ewes would be comparable to an interval between calvings of $12.0 \mathrm{mo}$ for (relatively) nonseasonal $500 \mathrm{~kg}$ cows. The STAR system has been used in the Cornell Dorset flock since 1981, but with little evidence for improvement in spring and summer fertility through 1987 [16].

Several studies have reported breed effects on fertility in accelerated lambing systems (e.g., [9, 29]). Among temperate breeds, most studies indicate that breeds of Merino ancestry (Rambouillet, Dorset) have relatively long breeding seasons [27] and are particularly responsive to effects of ram introduction on stimulation of ovulation and estrus [34]. The prolific breeds of Northern Europe such as the Finnish Landrace and Romanov also have been shown to perform well in spring matings [17,29]. In contrast, the British Down breeds and coarse-wooled breeds appear to both have a shorter breeding season [27] and be less responsive to ram introduction in spring [32].

Over the past half-century, there have been several efforts to develop lessseasonal lines of sheep $[7,21,39,45]$, but most ended before obtaining definitive results. Selection was generally based on fertility in spring or summer matings or in accelerated lambing systems. Heritability estimates for fertility in spring and summer matings are low, the trait is not expressed until late in life, data are generally recorded only in one sex (female), and the trait is expressed in only some lambing seasons and management systems, making genetic improvement through conventional means challenging. Selection schemes to shorten the seasonal anestrus and improve reproductive performance in accelerated lambing would thus benefit from identification of quantitative trait loci (QTL) influencing seasonality and the implementation of marker-assisted selection. This review will therefore focus on the development 


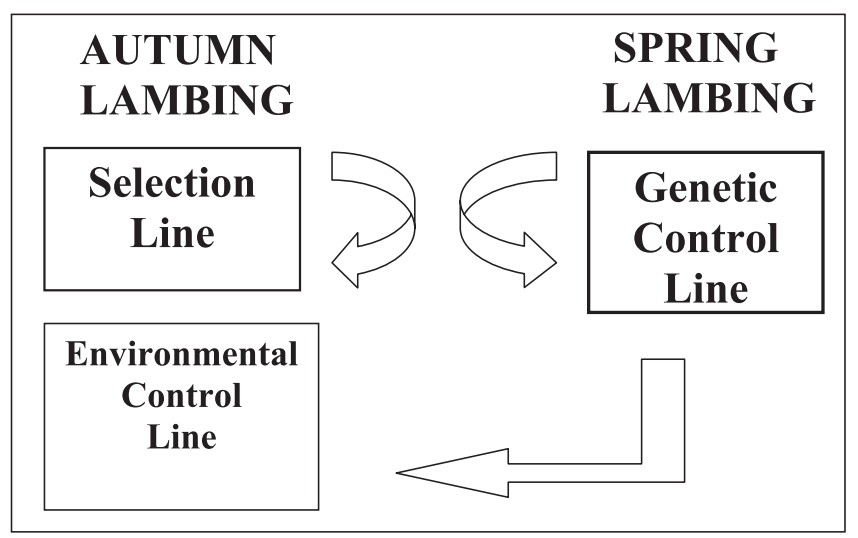

Figure 1. Experimental design of the Virginia Tech selection experiment.

of a population with reduced seasonality of breeding and on opportunities to detect associated QTL.

\section{THE VIRGINIA TECH OOS FLOCK}

\subsection{Design of the experiment}

The Virginia Tech out-of-season mating (OOS) line $[1,2,30]$ was developed by selection for fertility in May and June matings. These months correspond to the period of near-minimal fertility for most temperature breeds [27]. Threeway crosses of 50\% Dorset, 25\% Rambouillet, and 25\% Finnish Landrace breeding were used to establish the line. Following at least one generation of inter se autumn matings among three-way crosses, the base population was divided into three lines in 1988 (Fig. 1).

A selection line $(\mathrm{S})$ of 125 ewes and 10 rams was established in an annual spring mating system. These ewes were mated in single-sire breeding pastures for $60 \mathrm{~d}$ starting May 1. In phase 1 of the experiment (1988 through 1993), selection of replacements was based on the mean fertility of the ewes [1], and ewes were exposed to vasectomized rams for 2 weeks before breeding to attempt to induce ovulation and estrus by means of the ram effect [23]. In phase 2 (1994 through 1998), as mean fertility levels improved, teasing was discontinued, ewes were isolated from rams before the start of breeding, and a BLUP system of breeding value estimation was implemented based on a 1 or 0 binomial score for ewes that did or did not lamb in autumn [30]. In both phases, four to seven of the 10 rams and approximately one third of the ewes were replaced annually. 
A genetic control $(\mathrm{G})$ line of 45 ewes mated in October and early November was used as a source of unselected replacements. The $G$ line was managed to maximize generation interval and minimize inbreeding. Ewes were replaced only if they became unsound or failed to lamb in two consecutive years. Fourteen foundation sires were identified at the start of the project, and two randomly selected male descendants of these foundation rams were maintained. Five rams from this pool were used in single-sire matings in each year. Rams from eleven of the sire lines remained in the pool at the end of the selection in 1998. In addition, an environmental control line (E) of 55 ewes was maintained contemporary to $\mathrm{S}$ with spring mating. Unselected ewe lambs were transferred to $\mathrm{E}$ from the $\mathrm{G}$ line. In phase 1 of the experiment, $\mathrm{E}$ ewes were mated in single-sire pastures to five rams from the $\mathrm{G}$ line, but in phase 2, E ewes were mated to the $10 \mathrm{~S}$ rams to permit direct comparison of fertility of $\mathrm{S}$ and E ewes in the same breeding pastures. This design allowed E ewes to be both unselected and contemporary to $\mathrm{S}$, but also dictated that $\mathrm{E}$ ewes be an average of 7 mo older than $\mathrm{S}$ ewes.

\subsection{Response to selection}

The selection experiment ended in 1998 and the E and G lines were terminated at that time. However, selection has continued in the $\mathrm{S}$ line. Fertility was variable in the early years of the study, but by 1995, a substantial difference had emerged between lines and continued to increase through 1998 [30]. When mean estimated breeding values (EBV) for fertility of S, E, and G ewes mated in each year were regressed on year, resulting estimates of annual genetic trends were $1.98 \pm 0.04,0.61 \pm 0.15$, and $0.23 \pm 0.10 \% /$ year for $\mathrm{S}, \mathrm{E}$, and $\mathrm{G}$, respectively [30].

Significant ewe age effects on fertility and response to selection were observed (Tab. I) and highlight the difficulty in evaluating seasonality in young ewes. A cumulative selection response in fertility of $17 \%$ was observed in adult ewes, and a similar response of $18 \%$ was realized in 2 -year-old ewes. However, fertility of 7-mo-old ewe lambs in S exhibited little, if any, response to selection and was essentially unchanged from that observed in 1988. The $\mathrm{S}$ ewe lambs had lower fertility than E ewe lambs because of the greater age at first breeding in E lambs transferred from the genetic control line (Fig. 1).

\subsection{Characterization of OOS ewes}

The timing and duration of anestrus in OOS ewes was evaluated by maintaining high and low breeding value ewes with vasectomized rams from 
Table I. Mean fertility (\%) of select (S) and environmental control (E) ewes 1995-1997.

\begin{tabular}{lcc}
\hline Breeding & \multicolumn{2}{c}{ Flock } \\
\cline { 2 - 3 } opportunity $^{*}$ & $\mathrm{~S}$ & $\mathrm{E}$ \\
\hline First & 10 & 24 \\
Second & 76 & 58 \\
Third and greater & 87 & 70 \\
\hline
\end{tabular}

* S ewes were first mated at 7 to 8 mo of age whereas E ewes were first mated at 14 to 15 mo of age (Fig. 1).

mid-January through the following July and monitoring their mating behavior [46]. Only ewes that had lambed in the previous autumn (October and November) were used to ensure physiological comparability, and the same rams were used throughout the study to avoid possible induction of ram effect by introduction of novel males. In ewes evaluated in 1992, 1993, and 1995, the seasonal anestrus of high-fertility ewes from the $\mathrm{S}$ and $\mathrm{E}$ lines (mean EBV of $12.6 \%$ ) averaged only $28.4 \mathrm{~d}$ and was significantly shorter than the 70.1 $\mathrm{d}$ of anestrus observed in low-fertility ewes (mean EBV of $0.3 \%$ ). Vincent et al. [46] further reported that 13 OOS ewes evaluated in 1997 all exhibited nearly continuous cyclicity during spring and summer, with a mean period of anestrus of only $11.3 \mathrm{~d}$.

Ewes in the $\mathrm{S}$ line were shown to have lower nocturnal levels of circulating melatonin and higher nocturnal levels of circulating prolactin than $\mathrm{E}$ ewes [28]. Increases in fertility EBV were associated with declines in circulating melatonin $\left(-2.23 \pm 0.79 \mathrm{pg} \cdot \mathrm{mL}^{-1} \cdot \%^{-1}\right)$ and increases in circulating prolactin $\left(1.23 \pm 0.53 \mathrm{pg} \cdot \mathrm{mL}^{-1} . \%{ }^{-1}\right)$, suggesting that these animals may provide a model for understanding genetic control of secretion of these hormones.

\section{MELATONIN RECEPTOR 1A: A CANDIDATE GENE INFLUENCING SEASONALITY}

Molecular characterization of sequence variants in the ovine melatonin receptor la gene (MTNRIA) was reported by Barrett et al. [3] and Messer et al. [24]. Relative to the sequence for ovine MTNRIA reported by Reppert et al. [37], Barrett et al. [3] found a variant form with eight base changes, three of which resulted in amino acid substitutions in the receptor. Subsequent breed comparisons indicated that both forms of the gene were present in samples of six Greyface $\times$ Suffolk ewes, six Greyface $\times$ Dorset ewes, and six Soay rams (Tab. II). The presence of both forms of the gene was somewhat surprising in 
Table II. Allelic frequencies for the $M \ln \mathrm{I}$ and $R s a \mathrm{I}$ polymorphisms from the literature.

\begin{tabular}{|c|c|c|c|c|c|c|}
\hline \multirow[t]{2}{*}{ Breed } & \multirow{2}{*}{$\begin{array}{c}\text { Number } \\
\text { of } \\
\text { animals }\end{array}$} & \multicolumn{2}{|c|}{$M \ln \mathrm{I}$} & \multicolumn{2}{|c|}{$R s a \mathrm{I}$} & \multirow[t]{2}{*}{ Reference } \\
\hline & & Allele + & Allele - & Allele + & Allele - & \\
\hline Merino d'Arles & 142 & 0.63 & 0.37 & $-*$ & $-*$ & [35] \\
\hline Ile-de-France & 29 & 0.45 & 0.55 & -* & -* & [35] \\
\hline Suffolk & 18 & 0.67 & 0.33 & 0.08 & 0.92 & [24] \\
\hline Texel & 1 & 0.50 & 0.50 & 0.00 & 1.00 & [24] \\
\hline Coopworth & 4 & 0.75 & 0.25 & 0.00 & 1.00 & [24] \\
\hline Columbia & 57 & 0.84 & 0.16 & 0.03 & 0.97 & [49] \\
\hline Hampshire & 79 & 0.39 & 0.61 & 0.57 & 0.43 & [49] \\
\hline Greyface XB & 12 & 0.71 & 0.29 & -* & -* & [3] \\
\hline Soay & 6 & 0.75 & 0.25 & -* $^{*}$ & -* & [3] \\
\hline Han & 150 & 0.75 & 0.25 & 0.52 & 0.48 & [4] \\
\hline
\end{tabular}

*Not reported.

Table III. Allelic frequencies for the $M \ln \mathrm{I}$ and $R s a \mathrm{I}$ polymorphisms in various populations.

\begin{tabular}{lccccc}
\hline \multirow{2}{*}{ Population } & Number & \multicolumn{2}{c}{ MlnI } & \multicolumn{2}{c}{ RsaI } \\
\cline { 3 - 6 } & & Allele + & Allele - & Allele + & Allele - \\
\hline Virginia Tech OOS & 362 & 0.42 & 0.58 & 0.34 & 0.66 \\
Cornell Dorset & 24 & 0.31 & 0.69 & 0.64 & 0.36 \\
Tisdale Polypay & 19 & 0.47 & 0.53 & 0.76 & 0.24 \\
Israel Assaf & 2 & 0.50 & 0.50 & 0.00 & 1.00 \\
Israel Local Awassi & 7 & 0.07 & 0.93 & 0.31 & 0.69 \\
Israel Improved Awassi & 9 & 0.67 & 0.33 & 0.20 & 0.80 \\
\hline
\end{tabular}

the Soay, given the bottlenecks and small population sizes often postulated for this breed and suggested that these mutations arose early in the development of domestic sheep and had not been lost because of selection or random drift.

Messer et al. [24] identified two RFLP polymorphisms in MTNR1A in 36 OOS animals. Allelic frequencies were intermediate for both an MnlI polymorphism (0.39 and 0.61) and an RsaI polymorphism (0.39 and 0.61). However, the seasonal Suffolk breed $(n=18)$ was also polymorphic for both RFLP sites. Notter et al. [31] subsequently estimated allelic frequencies of 0.42 and 0.58 for the $M \ln \mathrm{I}$ polymorphism and of 0.34 and 0.66 for the RsaI polymorphism in the OOS flock (Tab. III) and further demonstrated that the polymorphisms were not independent in that flock. Only six of nine possible genotypes occurred with frequencies greater that 0.03 . 
A more detailed molecular analysis of MTNRIA was carried out by Pelletier et al. [35]. Ten mutations were observed in sequences from 30 Merino d'Arles ewes. Five of these corresponded to mutations identified by Barrett et al. [3] (and one of these was responsible for the $M n l I$ polymorphism), another corresponded to the RsaI polymorphism of Messer et al. [24], and four were newly discovered mutations. Two mutations resulted in amino acid substitutions, only one of which had been identified by Barrett et al. [3]. Animals homozygous for the absence of the MnlI site $(n=16)$ were also homozygous for three other mutations, including one that resulted in an amino acid substitution. In contrast, individuals homozygous for the presence of the $M n l$ site $(n=26)$ had three different arrangements of mutant alleles, one of which resulted in a change in amino acid sequence (at a different location than that observed for ewes that were homozygous for the absence of the $M n l I$ site).

Recent data from additional populations confirm that MTNR1A is polymorphic at both the $M \ln \mathrm{I}$ and $R s a \mathrm{I}$ restriction sites (Tab. III). Frequencies of both alleles at $M \ln \mathrm{I}$ were greater than 0.30 in the Cornell University Dorset flock, in a commercial Polypay flock in the United States, and in an improved Awassi flock in Israel. Frequencies of RsaI alleles were likewise between 0.20 and 0.80 in all populations except an Assaf flock in Israel (with a sample size of only two). The Dorset breed contributed to the formation of both the Polypay breed and the OOS population. Notter et al. [31] speculated that intermediate frequencies observed for $M \ln I$ alleles in the OOS flock may have resulted from the contribution of different alleles from different founder breeds, but results from the Cornell Dorset flock suggest that this was not the case.

Results in Tables II and III reveal substantial allelic diversity at the $M \ln I$ restriction site in MTNRIA in a number of breeds. All the breeds listed in Table III are under at least some selection for reduced seasonality. The Dorset and Polypay flocks have been selected for performance in accelerated lambing. The Cornell flock has had few introductions of outside breeding stock, although there was a link to a Dorset flock that also contributed to formation of the OOS flock. The Awassi and Assaf flocks are also maintained in frequent-lambing systems [10]. However, Table II reveals similar intermediate frequencies in the very seasonal Suffolk [24], Soay [3], and Ile-de-France [35] breeds. An alternative hypothesis of some form of heterozygote superiority involving these polymorphisms or the presence of unknown, very closely linked alleles naturally emerges but has not been tested. In goats, Migaud et al. [25] identified seven mutations with the caprine MTNRIA gene in 16 goats of the seasonal Alpine breed in France and 14 goats of the less seasonal Creole type 
from Guadeloupe. One amino acid changes was identified in the receptor, but no differences in allele frequencies were observed between these breeds.

Evidence for an association between MTNRIA and seasonal reproduction comes mainly from two sources. Pelletier et al. [35] compared genotypic frequencies for the $M n l \mathrm{I}$ polymorphism in 36 Merino d'Arles ewes with a history of spontaneous ovulatory activity in April (H ewes; identified by circulating progesterone levels in two jugular blood samples collected 8 to $10 \mathrm{~d}$ apart) and 35 ewes of the same breed that had not ovulated in this period (L ewes). The frequency of homozygotes for the presence of the MnlI restriction site (genotype ++ ) was significantly higher in $\mathrm{H}$ ewes $(52.8$ versus $28.5 \% ; P<0.001)$. Homozygotes for the absence of the restriction site (genotype --) were correspondingly less frequent in $\mathrm{H}$ ewes $(0.0 \%$ versus $28.5 \%)$. An analysis of genotypic frequencies within half-sibs $(21 \mathrm{H}$ and $29 \mathrm{~L}$ ewes $)$ yielded similar results, with frequencies of genotype -- of $0.0 \%$ in $\mathrm{H}$ ewes and $24.1 \%$ in $\mathrm{L}$ ewes $(P<0.01)$. Ewes of the seasonal Ile-de-France breed $(n=29)$ also had relatively low frequencies of genotype $++(28 \%$ versus $38 \%$ for --$)$. Differences in genotypic frequencies between the $\mathrm{H}$ and L Merino d'Arles ewes for the RsaI polymorphism were not significant.

In the OOS flock, sampling of DNA began in 1997, and 362 ewes were genotyped for the $M n l \mathrm{I}$ and $R s a \mathrm{I}$ polymorphisms between 1997 and 2000 [31]. Genotypic means for spring fertility and litter size were estimated for six high-frequency haplotypes. Genotypic effects on fertility were observed only when the analysis was restricted to records of adult (3 years old and older) ewes, which was not surprising given the low fertility of OOS ewe lambs (Tab. I). Among adult ewes, mean fertility varied among genotypes from 65.5 to $85.3 \%$. Ewes with at least one copy of the + allele at the MnlI restriction site had $11.2 \pm 5.1 \%$ higher spring fertility than ewes that were homozygous for the - allele $(P=0.03)$. Independent effects and interactions involving the two polymorphisms were difficult to assess given observed linkage disequilibrium, but there was no evidence for a direct impact of the $R s a$ I polymorphism on fertility. Effects of MTNRIA genotype on litter size were not significant.

Estimates of breeding values and dominance deviations for spring fertility were used to determine the proportion of the total additive variance that could be attributed to this gene and to partition the genotypic variance at the locus into additive and dominance components [13]. In adult ewes, estimates of total additive and permanent environmental variances for fertility were 151 and $148 \%^{2}$, respectively. Corresponding estimates of additive and dominance variances for the MTNR1A locus were 35.7 and $13.9 \%^{2}$, respectively. Thus these MTNR1A markers accounted for $23.8 \%$ of the additive variance for 
fertility, and dominance effects at this locus could account for $9.3 \%$ of the permanent environmental variance. These values highlight both the potential value of markers such as these and the challenges inherent in their identification. The heritability of spring fertility was $11 \%$ in adult matings. Thus while the markers account for nearly $25 \%$ of additive variance, they account for only about $2.5 \%$ of phenotypic variance, emphasizing the difficulty that will be involved in detection and accurate estimation of marker effects in other populations.

In a related study of the effects of these polymorphisms on reproduction, Chu et al. [4] reported effects of MTNRIA markers on litter size in Small-tailed Han sheep in China. The Small-tailed Han is a prolific breed [8] that expresses nonseasonal ovulatory activity and has been shown to have a high frequency of the $F e c B$ mutation at the bone morphogenic protein receptor IB gene [22]. In this study, ewes that were homozygous for the absence of the RsaI restriction site had larger litters at second parity than ewes that were homozygous for the presence of the restriction site $(3.19 \pm 0.13$ versus $2.25 \pm 0.12$ lambs/litter) and larger litters than heterozygous ewes at both first and second parity. Genotypic frequencies at the $M \ln \mathrm{I}$ site in this lowly seasonal breed revealed that animals of genotype -- were not present in this sample of 150 ewes, even thought heterozygotes were relatively frequent $(50.9 \%)$. Prior selection for fertility in spring matings or preferential use of ++ sires may have led to this unexpected distribution of genotypes at the $M \ln \mathrm{I}$ restriction site.

\section{CLOCK GENES: POSSIBLE EFFECTS ON SEASONAL REPRODUCTION}

Identification of mutations that disrupt circannual reproductive patterns and the introgression of such alleles into other populations could provide an effective means to reduce seasonality. Knowledge of genetic mechanisms controlling circannual rhythms remains limited, but information on genetic control of circadian rhythms in mammals is expanding rapidly, even though most studies involve laboratory rather than livestock species. Extension of these studies from circadian to circannual rhythms is far from trivial, but the various clock genes involved in circadian timekeeping may function as QTL influencing seasonal reproduction.

Eight major clock genes have been identified in mammals [14]: Clock, three Period genes (Per1, Per2, and Per3), BmalI, Timeless, and two Cryptochrome genes (Cryl and Cry2). These genes are distributed throughout the genome; in the mouse they are located on chromosomes $6,11,1,4,7,10,10$, and 2 , respectively [38]. Discussion of gene expression and the interactions involved 
in the establishment and maintenance of circadian rhythms at the cellular level can be found in Reppert and Weaver [37]. Briefly, autoregulatory feedback loops and the resetting and entrainment of these feedback loops by external stimuli (primarily, but not exclusively, light) are central components of the circadian clock. In the absence of external stimuli, these feedback loops, located primarily in the suprachiasmatic nucleus (SC) of the anterior hypothalamus, can maintain a daily circadian rhythm of approximately $24 \mathrm{~h}$. This circadian rhythm can be observed in a number of responses, including feed intake and sleep-wake patterns, but is most often measured by the daily period of locomotor activity which is commonly measured by wheel-running behavior in rodents and represented as $\tau$.

Various mutations in clock genes are known to interrupt this 24-h circadian activity rhythm. The tau mutation in the hamster Clock gene shortens the daily period of locomotor activity by $2 \mathrm{~h}$ in tau/+ individuals and by $4-\mathrm{h}$ in tau/tau homozygotes [36]. In contrast, the Clock ${ }^{M 1 J t}$ mutation in mice lengthens the circadian period in heterozygotes and abolishes it in homozygotes [47]. Two studies utilized mouse strains with abnormal circadian activity patterns to attempt to identify QTL associated with this behavior. Suzuki et al. [40] utilized $\mathrm{F}_{2}$ offspring of CS and C57BL/6J mice. Mice of the inbred CS strain are active in both the light and dark period, have a free-running circadian period of greater than $24 \mathrm{~h}$ in constant darkness, and have been shown to differ from C57BL/6J [5]. A QTL was identified on chromosome 19 and confirmed to influence the activity pattern in a second $\mathrm{F}_{2}$ family derived from crosses with MSM, a line derived from Japanese wild mice (Mus musculus molossinus). This locus accounted for $10.4 \%$ of $\mathrm{F}_{2}$ phenotypic variance in circadian period. Three additional suggestive QTL were detected: one on chromosome 12 and two others on chromosome 19. However, none of these QTL mapped to the location of a known clock gene. In a second study, Shimomura et al. [38] used $\mathrm{F}_{2}$ offspring of $\mathrm{C} 57 \mathrm{BL} / 6 \mathrm{~J}$ and $\mathrm{BALB} / \mathrm{cJ}$ mice, which have a circadian period of less than $23 \mathrm{~h}$, to identify 14 loci on 10 chromosomes with apparent effects on some aspect of circadian behavior. Markers that specifically affected the length of the circadian period were found on chromosomes 4, 5, and 12, but again did not correspond to the location of any known clock genes.

In sheep, gene expression studies are beginning to explore molecular regulation of the circadian clock. Expression of PERl in the pars tuberalis (PT) has been shown to be under photoperiodic control [26]. Expression of seven clock genes in the ovine SC and PT revealed effects of melatonin on phase relationships between PER and $C R Y$ genes in the PT but not the SC [18], suggesting a role for these genes in translation of melatonin signals into 
physiological responses. Lincoln et al. [20] further hypothesized the presence of "calendar cells" in the brain and pituitary gland that express a full complement of clock genes and provide a molecular basis for seasonal phenomena. In the ovine PT, activation of PER occurs early in the light phase, while activation of $C R Y$ occurs early in the dark phase [19]. In the SC, dimerization of the protein products of $P E R$ and $C R Y$ in the cytoplasm is required for translocation into the nucleus [15], so the interval between expression of PER and $C R Y$ may affect opportunities for dimerization of their gene products in cells of the PT, with potential effects on expression of other genes involved in reproductive function.

These results suggest that mutations in clock genes can affect circadian behavior patterns and may likewise influence more complex circannual rhythms. However, other QTL affecting quantitative variation in circadian behavior appear to exist independently of clock genes, a result that is perhaps not surprising, given the complex interactions and regulatory events involved in expression of these behaviors.

\section{PROSPECTS}

Development of populations with reduced seasonality is clearly possible through selection. However, identification of QTL and molecular markers could substantially augment selection responses. Studies to identify QTL affecting seasonal reproductive patterns in small ruminants are feasible given the very large between-breed variation in these patterns. Techniques to characterize the timing and duration of the seasonal anestrus [46] are labor-intensive but straightforward and informative and have modest facility and laboratory requirements. However, a substantial investment will be required to generate sufficient numbers of animals to allow accurate detection of QTL. Time requirements for such studies are also substantial. Fertility in spring and summer appears to be uniformly low in ewe lambs of all breeds. Useful variation among $\mathrm{F}_{2}$ ewes in seasonal fertility is expected only at the second and subsequent lambings. New techniques for QTL detection in outbred populations are emerging $[42,43]$ to compliment older approaches involving segregation analysis [6] and may be used in selection lines and commercial populations, but the complex management effects and interactions common in accelerated lambing systems will limit accuracy of individual-animal evaluation. Also, if fertility in spring and summer is the main phenotypic characteristic to be measured, issues of scaling arise. Crosses between seasonal and nonseasonal lines need not be intermediate to parent lines in realized fertility, and performance of $F_{1}$ 
animals may need to be carefully evaluated in order to help choose between $\mathrm{F}_{2}$ and backcross designs.

A search for, and characterization of effects of, mutants and sequence variants in candidate genes such as MTNRIA and the various clock genes should continue, since loss of function (i.e., loss of seasonality) relative to the wild type is desired and could possibly be induced by mutations in genes involved in regulation of circadian and circannual cycles. Study of these genes in livestock and laboratory studies will likely continue to expand, providing new information on mechanisms of gene expression and regulation in these complex systems, and with associated opportunities for their manipulation.

\section{ACKNOWLEDGEMENTS}

We would like to thank Elisha Gootwine for providing DNA from the Awassi and Assaf animals, Mike Thonney for providing DNA from the Cornell University Dorset flock, and Dwight and Sharon Tisdale for providing DNA from their Polypay animals.

\section{REFERENCES}

[1] Al-Shorepy S.A., Notter D.R., Genetic variation and covariation for ewe reproduction, lamb growth, and lamb scrotal circumference in a fall-lambing sheep flock, J. Anim. Sci. 74 (1996) 1490-1498.

[2] Al-Shorepy S.A., Notter D.R., Response to selection for fertility in a falllambing sheep flock, J. Anim. Sci. 75 (1997) 2033-2040.

[3] Barrett P., Conway S., Jockers R., Strosberg A.D., Guardiola-Lemaitre B., Delagrange P., Morgan P.J., Cloning and functional analysis of a polymorphic variant of the ovine Mel 1a melatonin receptor, Biochem. Biophys. Acta 1356 (1997) 299-307.

[4] Chu M.X., Ji C.L., Chen G.H., Association between PCR-RFLP of melatonin receptor 1a gene and high prolificacy in Small Tail Han sheep, Asian-Aust. J. Anim. Sci. 16 (2003) 1701-1704.

[5] Ebihara S., Tsuji K., Strain differences in the mouse's wheel-running behavior, Jpn. J. Psychol. Res. 18 (1976) 20-29.

[6] Elston R.C., Stewart J., A general model for the genetic analysis of pedigree data, Human Hered. 21 (1971) 523-542.

[7] Fahmy M.H., Development of DLS breed of sheep: genetic and phenotypic parameters of date of lambing and litter size, Can. J. Anim. Sci. 70 (1990) 771-778.

[8] Feng W., Ma Y., Zhang Z., Zhou D., Prolific breeds of China, in: Fahmy M.H. (Ed.), Prolific Sheep, CAB International, Wallingford, 1996, pp. 146-151. 
[9] Fogarty N.M., Dickerson G.E., Young L.D., Lamb production and its components in pure breeds and composite lines. I. Seasonal and other environmental effects, J. Anim. Sci. 58 (1984) 285-300.

[10] Gootwine E., Pollott G.E., Factors affecting milk production in improved Awassi dairy ewes, Anim. Sci. 71 (2000) 607-615.

[11] Hafez E.S.E., Studies on the breeding season and reproduction in the ewe, J. Agric. Sci. 42 (1952) 189-265.

[12] Hunter G.L., Increasing the frequency of pregnancy in sheep. I. Some factors affecting rebreeding during the post-partum period, Anim. Breed. Abstr. 36 (1968) 347-378.

[13] Jacquard A., The genetic structure of populations, Springer-Verlag, New York, 1974.

[14] King D.P., Takahashi J.S., Molecular genetics of circadian rhythms in mammals, Annu. Rev. Neurosci 23 (2000) 713-742.

[15] Kume K., Zylka M.J., Sriram S., Shearman L.P., Weaver D.R., Jin X., Maywood E.S., Hastings M.H., Reppert S.M., $m C R Y 1$ and $m C R Y 2$ are essential components of the negative limb of the circadian clock feedback loop, Cell 98 (1999) 193-205.

[16] Lewis R.M., Notter D.R., Hogue D.E., Magee B.H., Ewe fertility in the STAR accelerated lambing system, J. Anim. Sci. 74 (1996) 1511-1522.

[17] Leymaster K.A., Casas E., Freking B.A., Evaluation of Dorset, Finnsheep, Romanov, Texel, and Montadale breeds of sheep: Reproduction of $F_{1}$ ewes in spring mating seasons, J. Anim. Sci. 82 (2004) 390-391 (Abstr.).

[18] Lincoln G., Messager S., Andersson H., Hazlerigg D., Temporal expression of seven clock genes in the suprachiasmatic nucleus and the pars tuberalis of the sheep: evidence for an internal coincidence timer, Proc. Natl. Acad. Sci. USA 99 (2002) 13890-13895.

[19] Lincoln G., Andersson H., Hazlerigg D., Clock genes and the long-term regulation of prolactin secretion: evidence for a photoperiod/circannual timer in the pars tuberalis, J. Neuroendo. 15 (2003) 390-397.

[20] Lincoln G., Andersson H., Loudon A., Clock genes in calendar cells as the basis of annual timekeeping in mammals-a unifying hypothesis, J. Endocrinol. 179 (2003) 1-13.

[21] Lindahl I.L., Terill C.E., Lambing performance of Morlam ewes in 1972, J. Anim. Sci. 41 (1975) 251 (Abstr.).

[22] Liu S.F., Jiang Y.L., Du L.X., Studies of BMPR-IB and BMP15 as candidate genes for fecundity in Little Tailed Han sheep, Acta Genet. Sinic. 30 (2003) 755-760.

[23] Martin G.B., Oldham C.M., Cognie Y., Pearce D.T., The physiological responses of anovulatory ewes to the introduction of rams - a review, Livest. Prod. Sci. 15 (1986) 219-247.

[24] Messer L.A., Wang L., Tuggle C.K., Yerle M., Chardon P., Pomp D., Womack J.E., Barendse W., Crawford A.M., Notter D.R., Rothschild, M.F., Mapping of the melatonin receptor 1a (MTNR1A) gene in pigs, sheep, and cattle, Mamm. Genome 8 (1997) 368-370. 
[25] Migaud M., Gavet S., Pelletier J., Partial cloning and polymorphism of the melatonin $_{1 \mathrm{a}}\left(\mathrm{Mel}_{1 \mathrm{a}}\right)$ receptor gene in two breeds of goat with different reproductive seasonality, Reprod. 124 (2002) 59-64.

[26] Morgan P.J., Ross A.W., Graham E.S., Adam C., Messager S., Barrett P., oPerl is an early response gene under photoperiodic regulation in the ovine pars tuberalis, J. Neuroendo. 10 (1998) 319-323.

[27] Notter D.R., Genetic improvement of out-of-season breeding through selection, in: Proceedings of the Out-of-Season Breeding Symposium, 19-20 June 1992, Ames, Iowa, pp. 55-81.

[28] Notter D.R., Chemineau P., Nocturnal melatonin and prolactin plasma concentrations in sheep selected for fertility in autumn lambing, J. Anim. Sci. 79 (2001) 2895-2901.

[29] Notter D.R., Copenhaver J.S., Performance of Finnish Landrace crossbred ewes under accelerated lambing. I. Fertility, prolificacy and ewe productivity, J. Anim. Sci. 51 (1980) 1033-1042.

[30] Notter D.R., Al-Shorepy S.A., Vincent J.N., McQuown E.C., Selection to improve fertility in fall lambing, in: Proc. 6th World Cong. Genet. Appl. Livest. Prod., 11-16 January 1998, Vol. 27, University of New England, Armidale, pp. 43-46.

[31] Notter D.R., Cockett N.E., Hadfield T.S., Evaluation of melatonin receptor $1 a$ as a candidate gene influencing reproduction in a fall-lambing sheep flock, J. Anim. Sci. 81 (2003) 912-917.

[32] Nugent R.A. III, Notter D.R., Beal W.E., Effects of ewe breed and ram exposure on estrous behavior in May and June, J. Anim. Sci. 66 (1988) 1363-1370.

[33] Outhouse J.B., Drewry K.J., Mayo H., Stob M., Accelerated lambing program, Purdue University Ext. Mimeogr. AS-329, 1965.

[34] Pearce D.T., Oldham C.M., The ram effect, its mechanism and application to the management of sheep, in: Lindsay D.R., Pearce D.T. (Eds.), Reproduction in Sheep, Australian Academy of Science, Canberra, 1984, pp. 26-34.

[35] Pelletier J., Bodin L., Hanocq E., Malpaux B., Teyssier J., Thimonier J., Chemineau P., Association between expression of reproductive seasonality and alleles of the gene for $\mathrm{Mel}_{1 \mathrm{a}}$ receptor in the ewe, Biol. Reprod. 62 (2000) 1096-1101.

[36] Ralph M.R., Menaker M., A mutation of the circadian system in golden hamster, Science 241 (1988) 1225-1227.

[37] Reppert S.M., Weaver D.R., Molecular analysis of mammalian circadian rhythms, Annu. Rev. Physiol. 63 (2001) 647-676.

[38] Shimomura K., Low-Zeddies S.S., King D.P., Steeves T.D.L., Whiteley A., Kushla J., Zemenides P.D., Lin A., Vitaterna M.H., Churchill G.A., Takahashi J.S., Genome-wide epistatic interaction analysis reveals complex genetic determinants of circadian behavior in mice, Genome Res. 11 (2001) 959-980.

[39] Smith J.F., Johnson D.L., Reid T.C., Genetic parameters for performance of flocks selected for advanced lambing date, Proc. New Zealand Soc. Anim. Prod. 52 (1992) 50 (Abstr.). 
[40] Suzuki T., Ishikawa A., Yoshimura T., Namikawa T., Abe H., Honma S., Honma K., Ebihara S., Quantitative trait locus analysis of abnormal circadian period in CS mice, Mamm. Genome 12 (2001) 272-277.

[41] Taylor St. C.S., Genetic size scaling rules in animal growth, Anim. Prod. 30 (1980) 161-165.

[42] Thallman R.M., Bennett G.L., Keele J.W., Kappes S.M., Efficient computation of genotype probabilities for loci with many alleles: I. Allelic peeling, J. Anim. Sci. 79 (2001) 26-33.

[43] Thallman R.M., Bennett G.L., Keele J.W., Kappes S.M., Efficient computation of genotype probabilities for loci with many alleles: II. Iterative method for large, complex pedigrees, J. Anim. Sci. 79 (2001) 33-44.

[44] Thimonier J., Cognie Y., Cornu C., Schneberger J., Vernusse G., Intensive lamb production, Ann. Biol. Anim. Biochim. Biophys. 15 (1975) 365-367.

[45] Thrift F.A., Dutt R.H., Woolfolk P.G., Phenotypic response and time trends to date of birth selection in Southdown sheep, J. Anim. Sci. 33 (1971) 1216-1223.

[46] Vincent J.N., McQuown E.C., Notter D.R., Duration of the seasonal anestrus in sheep selected for fertility in fall lambing, J. Anim. Sci. 78 (2000) 1149-1154.

[47] Vitaterna M.H., King D.P., Chang A.M., Kornhauser J.M., Lowrey P.L., McDonald J.D., Dove W.F., Pinto L.H., Turek F.W., Takahashi J.S., Mutagenesis and mapping of a mouse gene, Clock, essential for circadian behavior, Science 264 (1994) 719-725.

[48] Walton P., Robertson H.A., Reproductive performance of Finnish Landrace ewes mated twice yearly, Can. J. Anim. Sci. 54 (1974) 35-40.

[49] Wright C.W., Polymorphisms at the melatonin (MTNR1A) gene and their association to reproductive performance in fall lambing ewes, M. S. Thesis, South Dakota State University, Brookings.

To access this journal online: www.edpsciences.org 
